\title{
THE SUBSTITUTION EFFECTS OF TAPIOCA STARCH AND BEETROOT POWDER AS FILLER ON THE PHYSICAL AND SENSORY CHARACTERISTICS OF CHICKEN SAUSAGE
}

\author{
Winny Swastike 1), ${ }^{*}$ Edi Suryanto ${ }^{2)}$, Rusman ${ }^{2)}$, Chusnul Hanim ${ }^{3)}$, Jamhari ${ }^{2)}$, Yuny Erwanto ${ }^{2)}$, Jumari ${ }^{2)}$ \\ 1) Animal Science Department, Faculty of Agriculture, Universitas Sebelas Maret, Jl. Ir Sutami No.36A, Jebres, \\ Kec. Jebres, Kota Surakarta, Jawa Tengah, Indonesia 57126 \\ ${ }^{2)}$ Department of Animal Products Technology, Faculty of Animal Science, Universitas Gadjah Mada, J1. Fauna \\ No.03, Karang Gayam, Caturtunggal, Kec. Depok, Kabupaten Sleman, Daerah Istimewa Yogyakarta, Indonesia \\ 55281 \\ ${ }^{3)}$ Department of Animal Feed and Nutrition, Faculty of Animal Science, Universitas Gadjah Mada, Jl. Fauna \\ No.03, Karang Gayam, Caturtunggal, Kec. Depok, Kabupaten Sleman, Daerah Istimewa Yogyakarta, Indonesia \\ 55281 \\ *Email: winny@staff.uns.ac.id
}

Submitted 11 March 2020; Accepted 11 June 2020

\begin{abstract}
Red beetroot is rich in phenolic acids and betalain as natural food-coloring agents. Freeze-dried red beetroot that ground into powder can be used as a source of natural coloring to substitute the use of synthetic food color additives as well as filler to substitute tapioca. This study evaluates the function of red beetroot powder not only as filler but also as coloring agent on chicken sausage. Furthermore, its effects as filler (tapioca and beetroot) were also observed on the physical and sensory characteristics of the produced chicken sausage. The substitution of tapioca flour and beetroot powder in this study were 18:0, 17:1, 16:2, and 15:3 (\%:\%). Each treatment was consisted of three replications. The examined physical properties include $\mathrm{pH}$, water-holding capacity (WHC) and sensory properties. The study found that WHC, color, texture profile and sensory properties were influenced by the increasing level of beetroot flour ratio, while different ratios had no effect on the $\mathrm{pH}$. Chicken sausages made with higher ratio of beetroot flour had good acceptability on flavor and color. The conclusions of this study were substitution tapioca with $2 \%$ beetroot powder influenced physical quality (water holding capacity and tenderness) and sensory (color and flavor) of chicken sausage.
\end{abstract}

Keywords: Red beetroot powder; substitution; filler 


\section{INTRODUCTION}

Chicken meat has been developed not only as a primary food for human consumption but also developed into derivative products such as sausage. The processing of chicken meat without any additives into sausage would result in a colorless product. Therefore, the food industry, especially chicken sausage used food additives such as synthetic coloring additive to produce an attractive sausage that resembles beef sausage. The color evaluation of processed meat provide significant information on eating quality properties. Previous study reported that the color of the meat changes during cooking (Abdulhameed et al., 2016). Myoglobin is a heme pigment that responsible for meat color and can change according the oxidation states, such as deoxymyoglobin, oxymyoglobin, metmyoglobin, and sulphate myoglobin.

It has been observed that during the thermal process, myoglobin structures changed into different forms due to the browning reactions, oxidation-reduction reactions, and oxygenation that affect the final meat color (García-Segovia et al., 2007; Saricoban and Yilmaz, 2010). Therefore, the addition of artificial or synthetic coloring agent is often required to produce more stable and brighter chicken sausage. However, the artificial coloring agent is not generally permitted due to the negative effect when consumed at certain concentrations.
Furthermore, due to the increasing demand of a healthy food, reduced-fat food and meat products with zero synthetic additive have gain popularity among consumers. Skinless chicken breast meat is known for its high protein but low-fat food, and has been viewed as a healthier alternative product. Many non-meat ingredients have been added to a variety of meat products to improve the nutrition value but maintain the quality of the products. Many kinds of fillers such as tapioca starch, potato, pumpkin, carrots (Yadav et al., 2018) and sweet potatoes powder were used in sausage production. However, filler substitution could affect the physical and sensory properties of the sausage. In addition, many non-meat ingredients that used as filling agents could affect the appearance, flavor, and texture of the foodproducts (Gravele et al., 2017), while also the lowering production cost as well.

The red beet (Beta vulgaris L. var. conditiva) is a native plant that is widely consumed in Indonesia. The plant has moderate calories but rich of sugars and dietary fibers (Straus et al., 2012). The consumption of red beet can help preventing aging as it is rich in phenolic acids and has high antioxidant capacity (Ravichandran et al., 2013). The natural coloring agent found in red beet is betalain, which contains two groups of red-violet (betacyanins) and yellow (betaxanthin) pigments, and these pigments together result in different intensity of red color. The betacyanin mainly present in the roots of the red beets is known

How to cite:

Swastike, W., Suryanto, E., Rusman., Hanim, C., Jamhari., Yuni Erwanto., \& Jumeri. (2020). The Substitution Effects of Tapioca Starch and Beetroot Powder as Filler On The Physical and Sensory Characteristics Of Chicken Sausage. Jurnal Ilmu dan Teknologi Hasil Ternak, 15 (2), 97-107 
as betanin (Nemzer et al., 2011). The compound has important antioxidant and natural coloring property (Georgiev et al., 2010). Some studies have been carried out focusing on the use of different types of beetroot for attaining these properties in emulsion-type sausages (Jin et al., 2014; Yildiz et al., 2016). Moreover, the usage of red beetroot powder provides a simple way of producing red-colored product in order to improve its nutritional value and also to provide decorated food to the consumer. Other non-meat ingredients commonly used on the meat processing and preservation are hydrocolloids or structuring additives. Starches are known as multifunctional food ingredients (Baranowska et al., 2004).

The application of starches could be used as adhesion, binding, emulsion stabilization, gelling, and moisture retention agents (Pietrasik, 1999). Tapioca flour as the source for starch could be used as binders to increase the emulsion characteristics of sausage. On the other hand, starches can act as fillers that bind water and fat (Heinz and Hautzinger, 2007). The addition of carbohydrates has been the commonly used to retain sensory properties of restructured meats by reducing fat content and improve the water holding capacity of the meat protein. Starches are commonly used in the meat industry to retain moisture by acting as coagulating agents through the formation of hydrogels. Starches are a popular ingredient and the use of starches as water binding agents in restructured meats is well established (Gravelle et al., 2017).

The different characteristics of filler would affect the characteristics of final product as well. Therefore, study on filler substitution by using beetroot powder to improve physical and sensory properties of chicken sausage becomes necessary. The objective of this study was to evaluate the substitution of beetroot powder as a filler and the effect on the physical also sensory properties of chicken sausage.

\section{MATERIALS AND METHODS}

\section{Materials}

The ingredients used in this study were breast chicken meat, beetroot powder, tapioca flour, soy protein isolate (SPI), spices (salt, fresh garlic, pepper powder), sodium tripolyphosphate (STTP), cooking oil, and ice water. Red beetroots were bought at a local market. The materials used in this experiment were grinder, meat chopper, penetrometer, electric digital scale, analytical scales, filter paper, cooking glove, stove, blender, $\mathrm{pH}$ meter, stainless steel pan and knife, thermometer, sausage casing, $35 \mathrm{~kg}$ weight bar, millimeter block paper, permanent markers and stopwatch.

\section{Methods}

The breast chicken meat, spices, tapioca flour and beetroot powder were prepared and mixed. Red beetroot powder was prepared in different levels to substitute tapioca flour. The substitution of tapioca flour and beetroot powder were 18:0, 17:1, $16: 2,15: 3(\% / \%)$. Each treatment was consisted of three replications. Prior to chopping, the red beetroots were washed and peeled. The chopped red beetroot was frozen at $-20^{\circ} \mathrm{C}$ overnight and then placed into a freeze dryer in three freezing stages (at PT. Pura Barutama, Kudus). The first stage was freezing at $-50^{\circ} \mathrm{C}$ and $-80^{\circ} \mathrm{C}$, the second stage was primary drying. In this phase, pressure is controlled through the application of partial vacuum. The vacuum sublimation by using condenser, and the last stage was secondary drying phase to remove unfrozen water molecules. All of the procedures were following the freeze 
machine manual at PT. Pura Barutama, Kudus. The dried product was ground into powder with the final moisture content of the red beet powder was at $3.5 \pm 0.5 \%$.

The skinless chicken breast meat was purchased from a local retailer. Any excessive subcutaneous fat and connective tissues were trimmed off the meat and the lean meat was minced through. Four batches were prepared for each treatment. The basic recipe consisted of $65 \%$ meat, $18 \%$ tapioca flour, $10 \%$ ice water and spices (garlic, pepper, salt). The minced meat was ground for 1 min by using a bowl cutter, and all of the ingredients were manually mixed for 2 min and followed with mixer machine for $15 \mathrm{~min}$. The other batters were made by substituting the tapioca flour percentage (1, 2 and 3\%) with red beetroot powder. The batter was stuffed into plastic sausage casings. The sausages were cooked in a steaming at internal temperature of $80^{\circ} \mathrm{C}$. The emulsified sausages were then cooled and analyzed.

\section{Physical characteristics}

The $\mathrm{pH}$ measured by using $\mathrm{pH}$ meter. The calibration was done before the test by using buffer solution and washed with distilled water. Measurements were made 3 times and then the results were obtained by measuring the average $\mathrm{pH}$ value (Bouton $e t$ al., 1971). Meat tenderness was observed by using penetrometer needle then the tenderness value was obtained from the average tenderness from three times measurement in the different meat spots Candogan and Kolsarici (2003). The water holding capacity test was performed by following Hamm (1986) method with modification. As much as $0.3 \mathrm{~g}$ meat sausage sample was pressed with $35 \mathrm{~kg}$ weight bar on a filter paper between two square glasses for $5 \mathrm{~min}$ (Soeparno, 2005).

\section{Sensory characteristics}

The sensory characteristics was evaluated by 25 panelists from Universitas Gadjah Mada, Yogyakarta. The panelists were selected based on the sausage intake frequency and experience in sensory evaluation of different types of meat products. The panelists evaluated each treatment in triplicates. The observed variables include color, taste, flavor, texture, firmness and acceptability of the chicken sausage by using the scoring method by (Kartika, 1988), with score of 1 showed bad or slightly extreme and 5 showed good or too extreme for each respected variable.

\section{Color}

The color of the sausage was measured using a CR-300 chromameter (Minolta Co., Japan) that was calibrated with a white plate prior to use.

\section{Data analysis}

The data of physical characteristics were analyzed statistically by using analysis of variance (ANOVA) and the differences between means were tested by Duncan's multiple range tests (Steel and Torrie, 1993). The data of sensory characteristic were analyzed by using non parametric test (Kruskal-Wallis test) (Steel and Torrie, 1993). The data of color measurement were analyzed descriptively.

\section{RESULTS AND DISCUSSION}

\section{Physical quality of chicken sausage}

The results of physical quality analysis of the chicken sausage with substitution different beetroot powder substitution levels are shown at Table 1. The physical quality of chicken sausages was observed by measuring the $\mathrm{pH}$, water holding capacity (WHC) and tenderness. 


\section{pH value}

The $\mathrm{pH}$ value of chicken sausage with the addition red beetroot powder are presented in Table 1. Based on the analysis of variance, red beetroot powder did not significantly affect the $\mathrm{pH}$ of chicken sausage. However, the increasing substitution level of red beetroot powder tended to increase the $\mathrm{pH}$ value but still within the acceptable range according to national standard (BSN, 2015). These findings are in line with the results of the research Yadav et al. (2017), which showed the $\mathrm{pH}$ value of chicken sausage with the addition of dried carrot and wheat bran were 5.96 to 6.36. Lengkey and Lobo (2016) also reported the same range of $\mathrm{pH}$ value (6.11 to 6.25) on native chicken sausage and had similar $\mathrm{pH}$ value of rabbit sausage. The $\mathrm{pH}$ value of the sausage batter is affected by the used meat, as well as the $\mathrm{pH}$ value of the non-meat ingredients including filling agents that are used for sausages processing (Soeparno, 2005). Beets have a $\mathrm{pH}$ ranging from 5.75 to 6.46 (Herbach et al., 2006) and the $\mathrm{pH}$ range of meat was from 5.96 to 6.07 (Van Laack et al., 2000).The $\mathrm{pH}$ value of the chicken sausage has the same range because all of the batter using the same meat ingredient, chicken meat, and the proportion dominated the sausage formulation.

Even the addition of beets can increase (Jin et al., 2014) or decrease the $\mathrm{pH}$ (Choi et al., 2017), but the addition of up to $3 \%$ red beetroot powder to substitute tapioca flour in this research did not affect $\mathrm{pH}$ of the chicken sausage. Thus, showed that the use of red beetroot powder until 3\% could substitute tapioca flour without affecting the $\mathrm{pH}$ value of chicken sausage.

Table 1. The $\mathrm{pH}$ value, water holding capacity, and tenderness of chicken sausage with different substitution level of beetroot powder

\begin{tabular}{ccccc}
\hline \multirow{2}{*}{ Physical qualities } & \multicolumn{4}{c}{ Treatments } \\
\cline { 2 - 5 } & $\mathrm{T} 0$ & $\mathrm{~T} 1$ & $\mathrm{~T} 2$ & $\mathrm{~T} 3$ \\
\hline $\mathrm{pH}$ valuens & $6.57 \pm 0.29$ & $6.57 \pm 0.28$ & $6.57 \pm 0.04$ & $6.57 \pm 0.29$ \\
WHC $(\%)$ & $62.44 \pm 2.02 \mathrm{a}$ & $64.62 \pm 1.7 \mathrm{bc}$ & $63.1 \pm 1.39 \mathrm{ab}$ & $66.16 \pm 0.7 \mathrm{c}$ \\
Tenderness $(\mathrm{mm} / 50 \mathrm{~g} / \mathrm{s})$ & $9.49 \pm 0.89 \mathrm{a}$ & $9.67 \pm 0.53 \mathrm{a}$ & $10.67 \pm 1.11 \mathrm{ab}$ & $10.95 \pm 1.05 \mathrm{~b}$ \\
\hline
\end{tabular}

Description: Mean \pm SD, $n=5$. ns Not significant. a,b,c Different superscripts at the same row indicate significant differences $(P<0.05)$.

\section{Water-holding capacity (WHC)}

Water-holding capacity is the ability of meat to retain moisture during cutting, heating, grinding and processing (Soeparno, 2005). The water-holding capacities of chicken sausages with beetroot powder are presented in Table 1.

Beetroot powder substitution levels significantly affected the water-holding capacity of chicken sausage $(\mathrm{P}<0.05)$. The increasing substitution levels of beetroot powder would increase the WHC of chicken sausage. This is due to the fact that beetroot powder has a larger particle size compared to tapioca flour, which will cause increased water holding capacity. According to Bouton et al. (1972) the water-binding of meat protein are affected by $\mathrm{pH}$.

The $\mathrm{pH}$ at above the isoelectric point is needed to bind water (the isoelectric point was 5.0 - 5.2). According to Aberle et al. (2001), water-holding capacity is affected by $\mathrm{pH}$ and increased $\mathrm{pH}$ value was a linear correlation with increasing WHC (Swatland, 1984). At $\mathrm{pH}$ values higher than the isoelectric point, a number of positive 
charges are freed and there is a surplus of negative charges which results in myofilaments repelling and giving more space to water (Soeparno, 2005). The high amount of protein is responsible to increase the binding capacity of sausage water. Sun et al. (2011) found that the myofibrillar proteins was primarily affected by salting and cooking structurally, resulting in the changes in protein functionalities, e.g. water-binding ability. Soeparno (2005) state that the ability to bind water to meat products will be in accordance with the protein levels present in these meat products. The higher protein content would cause higher water binding capacity of the meat product. According to Gravelle et al. (2017), when the $\mathrm{pH}$ increases the protein becomes more negatively charged.

The high negative charge will increase the repulsive power between proteins in myofibrils. Myofibrils would expand and retain water which causes an increase in water content. The ability of myofibrillar proteins to stabilize the water phase rapidly degraded with increasing particle size, requiring a much higher filler content to eliminate liquid losses. It means that tapioca flour particle was smaller than beetroot powder and the associated increased surface area available to interact with water.

\section{Tenderness}

Tenderness or also called elasticity in meat product is the structural changes against resistance to breakage due to compressive forces that can change its shape. The pressure on the product caused a change in the product and then solves the product. This property is essential concerning the quality of food products in the gel form. The tenderness value of chicken sausage with beetroot powder substitution was significantly different $(\mathrm{P}<0.05)$. The increasing substitution levels of beetroot powder significantly increase the chicken sausage tenderness. The greater sausage tenderness can be interpreted with the decrease of sausage elasticity. Research showed that the denaturation of myofibrillar proteins make the meat tougher, but the gelatinization of connective tissue retenderizes the meat (Sanghoon et al., 2011).

The combination of myofibrillargelatin sources affects the gel strength or hardness (Brewer et al., 2005) and reduce the fat emulsion of meat products (Matulis et al., 1995). The tenderization of meat could be related to the weakening of the connective tissue caused by the thermal generation of gelatin which improved meat tenderness (Dhanapal et al., 2012; Kong et al., 2008).

\section{Sensory quality of chicken sausage}

As shown in Table 2, the color, flavor, tenderness, juiciness, texture and the acceptability of chicken sausage was affected differently by the addition of beetroot powder.

\section{Color}

Color showed significant effects from beetroot powder substitutions in emulsified sausages $(\mathrm{P}<0.05)$. The results showed that the substitution levels of beetroot powder affect the redness color. Higher redness color made chicken sausage become more attractive for the consumer.

In this research, the increased substitutions beetroot powder level also increased red color intensity. The betalain contain in beetroot powder contributed increasing redness. Delgado-Vargas (2000) explained that betalain is abundant in parts of plants such as flowers, roots, fruits and leaves. Beetroot contains betalain which produces a purplish red color. 


\section{Flavor}

As shown in Table 2, the chicken sausage flavor had significant difference $(\mathrm{P}<0.05)$ between treatments. The results showed that the flavor was decreased due to the earthy taste of the beetroot powder, which contribute into sensory parameter. The higher beetroot powder substitution levels also increased the earthy taste in chicken sausage.

The earthy taste found in the red beets was due to the geosmin compound found in the red beets (Lu, et al, 2003). Geosmin (trans-1, 10-dimethyl-trans-9-decalol) is a secondary volatile aromatic metabolite compound responsible for the characteristic flavor of the soil in red beets ( $\mathrm{Lu}$, et. Al., 2003).

\section{Juiciness}

As shown in Table 2, the juiciness of chicken sausages showed no significant difference among treatments. The increased beetroot powder level in chicken sausages did not affect the juiciness, even though slight increase of the juiciness was found along the increased beetroot powder level. The results are in line with Choi et al. (2010) which added fiber from rice bran and hazelnut pellicle to emulsion-type sausage.

\section{Texture}

The effect of beetroot powder addition on the texture of chicken sausages was not significant (Table 2). Texture is meat characteristics that related to the coarseness of meat fiber. There were not any differences in the texture with increasing beetroot powder level.

Sausage batter with increased beetroot powder did not affect the emulsion, thus did not decrease the sausage texture as well. Emulsion would decrease the texture. The factors that influence the measurement of texture is water content. The tenderness is achieved due to the higher thermal denaturation of myofibrillar proteins and collagen as confirmed by previous studies (García-Segovia et al., 2008; Khan et al., 2014).

The decrease in the hardness of meat products during cooking occurs as the cell stiffness is declining, starch is gelatinized and the cell wall bonds are weakened (Verlinden et al., 1995). In addition, it was observed that there was a remarkable tenderizing effect post thermal processing due to the denaturation of proteins induced by high temperature exposure and also due to the uncoiling of polypeptide chains (Dhanapal et al., 2012)

Table 2. The sensory qualities of chicken sausage with different of beetroot powder substitution levels

\begin{tabular}{cllll}
\hline \multirow{2}{*}{ Sensory qualities } & \multicolumn{4}{c}{ Treatments } \\
\cline { 2 - 5 } & \multicolumn{1}{c}{$\mathrm{T} 0$} & \multicolumn{1}{c}{$\mathrm{T} 1$} & \multicolumn{1}{c}{$\mathrm{T} 2$} & \multicolumn{1}{c}{$\mathrm{T} 3$} \\
\hline Color & $1.01 \pm 0.11 \mathrm{a}$ & $1.65 \pm 0.58 \mathrm{~b}$ & $2.91 \pm 0.72 \mathrm{c}$ & $2.91 \pm .72 \mathrm{c}$ \\
Flavor & $3.69 \pm 0.78 \mathrm{~b}$ & $3.53 \pm 0.79 \mathrm{ab}$ & $3.37 \pm 0.8 \mathrm{a}$ & $3.37 \pm 0.8 \mathrm{a}$ \\
Juiciness & $2.88 \pm 0.85$ & $2.99 \pm 0.7$ & $3.03 \pm 0.75$ & $3.03 \pm 0.7$ \\
Texture & $3.11 \pm 0.83$ & $3.11 \pm 0.74$ & $3.16 \pm 0.75$ & $3.16 \pm 0.75$ \\
Acceptability & $3.52 \pm 0.9$ & $3.44 \pm 0.81$ & $3.29 \pm 0.87$ & $3.29 \pm 0.87$ \\
\hline
\end{tabular}

Description: Mean \pm SD, $n=5$. a,b,c,d Different superscript at the same row indicated a significant difference $(\mathrm{P}<0.05)$. 


\section{Overall acceptance}

As shown in Table 2, there was no significant difference among treatments in overall acceptance. Generally, it is observed that increasing beetroot powder up to $3 \%$ did not alter the acceptance of chicken sausage.

\section{CONCLUSION}

This study concludes that the substitution of tapioca with $2 \%$ beetroot powder influenced physical (water holding capacity and tenderness) and sensory (color and flavor) quality of chicken sausage.

\section{ACKNOWLEDGMENTS}

The authors would like to thank the Direktorat Riset dan Pengabdian kepada Masyarakat (DRPM) Ditjen Penguatan Riset dan Pengembangan on funding of Hibah Disertasi Doktor (PDD) TA 2018 with contract number 474/UNS27.21/PP/2018 for financing the research and PT. Pura Barutama, Kudus for freeze drying machine to make beetroot powder.

\section{REFERENCES}

Abdulhameed, A., Yang, T., \& Abdulkarim, A. (2016). Kinetic of texture and colour changes in chicken sausage during superheated steam cooking. Polish Journal of Food and Nutrition Sciences, 66(3), 199-209. https://doi. org/10.1515/pjfns-2015-0044

Baranowska, H. M., Rezler, R., Poliszko, S., Dolata, W., Piotrowska, E., \& Piatek, M. (2004). Starch As A Functional Addition In Meat Batters. In Starch Containing Sources To Isolation Of Starches And Their Applications (pp. 115-123). Nova Science Publishers, Inc.
Bouton, P. E., \& Harris, P. V. (1972). The effects of cooking temperature and time on some mechanical properties of meat. Journal of Food Science, 37(1), 140-144. https://doi.org/10.1111/j.13 65-2621.1972.tb03404.x

Bouton, P. E., Harris, P. V., \& Shorthose, W. R. (1971). Effect of ultimate $\mathrm{pH}$ upon the water-holding capacity and tenderness of mutton. Journal of Food Science, 36(3), 435-439. https://doi.org /10.1111/j.1365-2621.1971.tb06382.x

Candogan, K., \& Kolsarici, N. (2003). The effects of carrageenan and pectin on some quality characteristics of low-fat beef frankfurters. Meat Science, 64(2), 199-206. https://doi.org/10.1016/S03 09-1740(02)00181-X

Choi, Y.-S., Kim, T.-K., Jeon, K.-H., Park, J.-D., Kim, H.-W., Hwang, K.-E., \& Kim, Y.-B. (2017). Effects of preconverted nitrite from red beet and ascorbic acid on quality characteristics in meat emulsions. Korean Journal for Food Science of Animal Resources, 37(2), 288-296. https://doi.org/10.58 51/kosfa.2017.37.2.288

Choi, Y.-S., Park, K.-S., Choi, J.-H., Kim, H.-W., Song, D.-H., Kim, J.-M., Chung, H.-J., \& Kim, C.-J. (2010). Physico-chemical properties of chicken meat emulsion systems with dietary fiber extracted from makgeolli lees. Korean Journal for Food Science of Animal Resources, 30(6), 910-917. https://doi.org/10.5851/kosfa.2010.30 .6 .910

Delgado-Vargas, F., Jiménez, A. R., \& Paredes-López, O. (2000). Natural 
pigments: carotenoids, anthocyanins, and betalains - characteristics, biosynthesis, processing, and stability. Critical Reviews in Food Science and Nutrition, 40(3), 173-289. https:// doi.org/10.1080/10408690091189257

Dhanapal, K., Vidya Sagar Reddy, G., Bushan Naik, B., Venkateswarlu, G., Devivaraprasad Reddy, a, \& Basu, S. (2012). Effect of cooking on physical, biochemical, bacteriological characteristics and fatty acid profile of Tilapia (Oreochromis mossambicus) fish steaks. Archives of Applied Science Research, 4(2), 1142-1149.

García-Segovia, P., Andrés-Bello, A., \& Martínez-Monzó, J. (2007). Effect of cooking method on mechanical properties, color and structure of beef muscle (M. pectoralis). Journal of Food Engineering, 80(3), 813-821. https:// doi.org/10.1016/j.jfoodeng.2006.07.010

Georgiev, V. G., Weber, J., Kneschke, E.-M., Denev, P. N., Bley, T., \& Pavlov, A. I. (2010). Antioxidant activity and phenolic content of betalain extracts from intact plants and hairy root cultures of the red beetroot beta vulgaris cv. detroit dark red. Plant Foods for Human Nutrition, 65(2), 105-111. https://doi.org/10.1007/s111 30-010-0156-6

Gravelle, A. J., Barbut, S., \& Marangoni, A. G. (2017). Food-grade filler particles as an alternative method to modify the texture and stability of myofibrillar gels. Scientific Reports, 7(1), 415-425. https://doi.org/10.1038/s41598-017-1 1711-1
Hamm, R. (1986). Functional Properties Of Myofibrillar System And Their Measurement. In P. J. Bechtel (Ed.), Muscle as Food (pp. 135-199). Academic Press.

Heinz, G., \& Hautzinger, P. (2007). Meat Processing Technology, For Small- To medium-Scale Producers. FAO.

Herbach, K. M., Stintzing, F. C., \& Carle, R. (2006). Betalain stability and degradation? structural and chromatic aspects. Journal of Food Science, 71(4), R41-R50. https://doi.org/10.11 11/j.1750-3841.2006.00022.x

Jin, S.-K., Choi, J.-S., Moon, S.-S., Jeong, J.-Y., \& Kim, G.-D. (2014). The assessment of red beet as a natural colorant, and evaluation of quality properties of emulsified pork sausage containing red beet powder during cold storage. Korean Journal for Food Science of Animal Resources, 34(4), 472-481. https://doi.org/10.5851/kos fa.2014.34.4.472

Kartika, B., Hastuti, P., \& Supartono, W. (1988). Pedoman Uji Indrawi Bahan Pangan. In Pangan dan Gizi. UGM.

Ko, S., Yoo, S.-H., Lee, S., Cho, S., Kim, K.H., \& Hwang, R. (2010). Effect of long low temperature-short high temperature cooking cycle on physicochemical properties of beef. Food Science and Technology Research, 17(1), 11-16. https://doi.org /10.3136/fstr.17.11

Kong, F., Tang, J., Lin, M., \& Rasco, B. (2008). Thermal effects on chicken and salmon muscles: Tenderness, cook 
loss, area shrinkage, collagen solubility and microstructure. LWT Food Science and Technology, 41(7), 1210-1222. https://doi.org/10.1016/ j.lwt.20 07.07.020

Lengkey, H. A. W., \& Lobo, B. R. (2016). Physico-chemical and microbiological characteristics, sensory quality and acceptability of native chicken and rabbit sausage produced with corn oil, margarine and beef fat. Macedonian Veterinary Review, 39(2), 193-199. https://doi.org/10.1515/macvetrev-20 16-0087

Lu, G., Edwards, C. G., Fellman, J. K., Mattinson, D. S., \& Navazio, J. (2003). Biosynthetic origin of geosmin in red beets (Beta vulgaris L.). Journal of Agricultural and Food Chemistry, 51(4), 1026-1029. https://doi.org/10. 1021/jf020905r

Matulis, R. J., Mckeith, F. K., Sutherland, J. W., \& Brewer, M. S. (1995). Sensory characteristics of frankfurters as affected by salt, fat, soy protein, and carrageenan. Journal of Food Science, 60(1), 48-54. https://doi.org/10.1111/ j.1365-2621.1995.tb05604.x

Nemzer, B., Pietrzkowski, Z., Spórna, A., Stalica, P., Thresher, W., Michałowski, T., \& Wybraniec, S. (2011). Betalainic and nutritional profiles of pigmentenriched red beet root (Beta vulgaris L.) dried extracts. Food Chemistry, 127(1), 42-53. https://doi.org/10.101 6/j.foodchem.2010.12.081

Pietrasik, Z. (1999). Effect of content of protein, fat and modified starch on binding textural characteristics, and colour of comminuted scalded sausages. Meat Science, 51(1), 17-25. https://doi.org/10.1016/S0309-1740 (98) 00068-0

Ravichandran, K., Saw, N. M. M. T., Mohdaly, A. A. A., Gabr, A. M. M., Kastell, A., Riedel, H., Cai, Z., Knorr, D., \& Smetanska, I. (2013). Impact of processing of red beet on betalain content and antioxidant activity. Food Research International, 50(2), 670675. https://doi.org/10.1016/j.foodres. 2011.07 .002

Saricoban, C., \& Tahsin Yilmaz, M. (2010). Modelling the effects of processing factors on the changes in colour parameters of cooked meatballs using response surface methodology. World Applied Sciences Journal, 9(1), 14-22.

Sasa, S., Franc, B., Matjaz, T., Ana, S., Crtomir, R., \& Martina, B. (2012). Nutritional value and economic feasibility of red beetroot (Beta vulgaris L. ssp. vulgaris Rote Kugel) from different production systems. African Journal of Agricultural Research, 7(42), 5653-5660. https:// doi.org/10.5897/AJAR12.1519

Soeparno. (2005). Ilmu dan Teknologi Daging (4th ed.). Gadjah Mada University Press.

Stintzing, F. C., Herbach, K. M., Mosshammer, M. R., Carle, R., Yi, W., Sellappan, S., Akoh, C. C., Bunch, R., \& Felker, P. (2005). Color, betalain pattern, and antioxidant properties of cactus pear (Opuntia spp.) clones. Journal of Agricultural and Food 
Chemistry, 53(2), 442-451. https://doi. org/10.1021/jf048751y

Van Laack, R. L. J., Liu, C.-H., Smith, M. O., \& Loveday, H. D. (2000). Characteristics of pale, soft, exudative broiler breast meat. Poultry Science, 79(7), 1057-1061. https://doi.org/10.1 093/ps /79.7.1057

Verlinden, B. E., Nicolaï, B. M., \& De Baerdemaeker, J. (1995). The starch gelatinization in potatoes during cooking in relation to the modelling of texture kinetics. Journal of Food Engineering, 24(2), 165-179. https:// doi.org/10.1016/0260-8774(94)P2641-H
Yadav, S., Pathera, A. K., Islam, R. U., Malik, A. K., \& Sharma, D. P. (2018). Effect of wheat bran and dried carrot pomace addition on quality characteristics of chicken sausage. Asian-Australasian Journal of Animal Sciences, 31(5), 729-737. https://doi. org/10.57 13/ajas.17.0214

Yildiz T, G., Kazan, H., \& Unubol, H. (2016). The usage of red beet powder as natural colorant and antioxidant in sausage production. Celal Bayar University Journal of Science, 12(2), 303-311. 